\title{
Modelling of root reinforcement and erosion control by 'Veronese' poplar on pastoral hill country in New Zealand
}

\author{
M. Schwarz ${ }^{1,2 *}$, C. Phillips ${ }^{3}$, M. Marden ${ }^{4}$, I. R. Mclvor ${ }^{5}$, G. B. Douglas ${ }^{6}$ and A. Watson ${ }^{7}$
}

\begin{abstract}
Background: The control of erosion processes is an important issue worldwide. In New Zealand, previous studies have shown the benefits of reforestation or bioengineering measures to control erosion. The impetus for this work focuses on linking recent research to the needs of practitioners by formulating quantitative guidelines for planning and evaluation of ground bioengineering stabilisation measures.

Methods: Two root distribution datasets of 'Veronese' poplar (Populus deltoides x nigra) were used to calibrate a root distribution model for application on single root systems and to interacting root systems at the hillslope scale. The root distribution model results were then used for slope stability calculations in order to quantitatively evaluate the mechanical stabilisation effects of spaced trees on pastoral hillslopes.

Results: This study shows that root distribution data are important inputs for quantifying root reinforcement at the hillslope scale, and that root distribution strongly depends on local environmental conditions and on the tree planting density. The results also show that the combination of soil mechanical properties (soil angle of internal friction and cohesion) and topographic conditions (slope inclination) are the major parameters to define how much root reinforcement is needed to stabilise a specific slope, and thus the spacing of the trees to achieve this.

Conclusions: For the worst scenarios, effective root reinforcement $(>2 \mathrm{kPa}$ ) is reached for tree spacing ranging from 2500 stems per hectare (sph) for $0.1 \mathrm{~m}$ stem diameter at breast height (DBH) to 300 sph for $0.3 \mathrm{~m}$ stem DBH. In ideal growing conditions, tree spacing less than $100 \mathrm{sph}$ is sufficient for stem DBH greater than $0.15 \mathrm{~m}$. New quantitative information gained from this study can provide a basis for evaluating planting strategies using poplar trees for erosion control on pastoral hill country in New Zealand.
\end{abstract}

Keywords: Shallow landslides, Land use, Root reinforcement, Bioengineering

\section{Background}

Globally, many different forms of land use, driven from different socio-economic needs, produce a variety of anthropised landscapes that in some cases lead to significant changes in geomorphological processes. While some traditional land uses reduce the intensity of processes such as floods or shallow landslides (Sidle and Ochiai, 2006), other types of land use lead to an acceleration of such processes (e.g. Phillips and Marden, 2005; Marden and Rowan 2015). Pastures established on steep $\left(20-35^{\circ}\right)$ hillslopes in

\footnotetext{
* Correspondence: massimiliano.schwarz@bfh.ch

${ }^{1}$ Bern University of Applied Sciences, 3052 Zollikofen, Switzerland

${ }^{2}$ Swiss Federal Institute for Forest, Snow and Landscape Research, 8903

Birmensdorf, Switzerland

Full list of author information is available at the end of the article
}

New Zealand for livestock grazing is an example of land use which over a long period has caused major issues from a landscape management perspective (Blaschke et al. 1992). In particular, shallow landslides cause considerable losses of productive soil and represent a challenge for risk management in such systems (Heaphy et al. 2014). Furthermore, landslide scars may contribute to further erosion from other processes that may cause continuing on- and off-farm effects including enhanced loss of soil productivity, water holding capacity, and decline in water quality of streams and rivers. It is estimated that for each high-magnitude storm event, with estimated return periods in excess of $20-50$ years, regionally, up to $10 \%$ of soil area on steep pastoral hillslopes may be lost and as 
high as $36 \%$ lost on individual properties (Marden et al. 1995; Dymond et al. 2006; Rosser and Ross 2011). Studies have also shown that the recovery of soil productivity on shallow landslide-eroded areas takes many years, with annual pasture production unlikely to attain more than $80 \%$ of that of un-eroded ground over many decades (Douglas et al. 1986; Lambert et al. 1984; Rosser and Ross 2011).

The benefits of reforestation or bioengineering measures to control erosion have also been demonstrated (e.g. Pearce et al. 1987; Phillips et al. 1990; Blaschke et al. 2008; McIvor et al. 2011; Marden 2012; Phillips et al. 2012). In New Zealand pastoral hill country, widespaced trees of poplar (Populus spp.) and willow (Salix spp.) have been the primary means of erosion control for 50+ years (Wilkinson, 1999). These species are established using 2.5- to 3.0-m-long poles (vegetative cuttings), with plastic sleeve protectors, and planted on slopes at a spacing of $10-15 \mathrm{~m}$ depending on erosion potential and practitioner experience. These trees add value to hill pastoral systems through providing shade, shelter, quality fodder (summer/autumn), and carbon sequestration (Wall et al. 1997; Betteridge et al. 2012; Basher 2013), increasing their utilisation and further adoption by landowners. A mix of clones is usually planted, and they are managed for at least the first 5 years after planting. In some regions, treatment of erosion-prone pastoral areas has shifted from being farmer-led and voluntary to becoming a requirement promoted (and generally incentivised) or regulated by the local authorities.

Wide-spaced tree plantings over a range of sizes (ages) have been shown to reduce the occurrence of shallow landslides on pastoral slopes by up to $95 \%$, when compared with areas of similar topography without trees (Hawley and Dymond 1988; Dymond et al. 2006; McIvor et al. 2011; Douglas et al. 2013). In order to formulate consistent guidelines for practitioners, quantitative data and effective methods, models, and tools are required. A better understanding of the landslide process and the effect of root reinforcement on slope stability should support current planting guidelines and allow better quantification of how and when stability is increased with different tree spacings as trees mature (Fig. 1). Fundamental steps in such a quantitative approach are firstly the spatial characterisation of root distribution and secondly the calculation of root reinforcement.

Some knowledge and understanding of how widespaced trees contribute to slope stabilisation is provided by limited data on the root distribution of young ( $<12$ years) poplar and willow trees on slopes (McIvor et al. 2008; McIvor et al. 2009; Douglas et al. 2010). However, although significant advances in understanding have been made in the last decade, and are being used to refine planting recommendations, a key gap is linking the mechanical quantification of root reinforcement with its effects on slope stability. The framework proposed by Schwarz et al. (2010a) provides an opportunity to upscale root distribution data to the stand scale, calculate root reinforcement, and thus discuss its effects on slope stability.

Methods to quantify root reinforcement have been developed over the last 35 years. The major advance in these has been the introduction of the fibre bundle model concept by Pollen (2005) which applied a stress-step loading approach to consider the progressive failure of roots

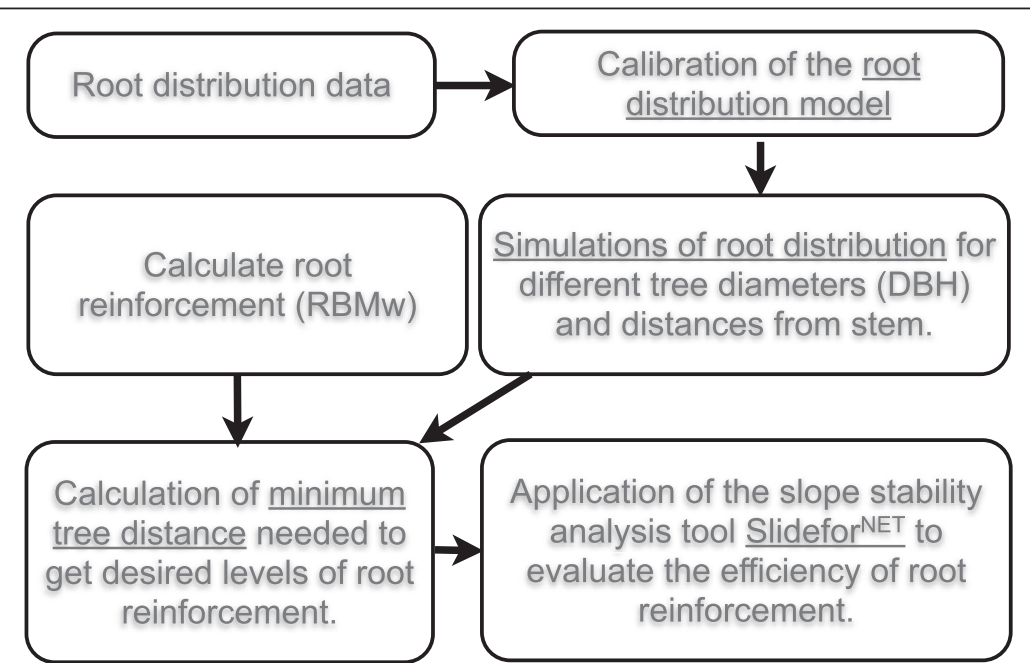

Fig. 1 Flowchart of the material and methods used for the quantification of minimum tree distances to get the needed root reinforcement in order to reduce erosion on pastoral hillslopes 
with different root diameters. This was further extended in the 'Root Bundle Model' (RBMw; Schwarz et al. 2013) which is characterised by the following features:

- The model uses a strain-step loading approach to calculate the force-displacement behaviour of each single root of a bundle while considering the progressive failure of the roots as a function of displacement.

- The model uses a Weibull survival function that describes the range of probability that a single root failed before or after the fitted value of maximum tensile force estimated based on its diameter class. This function considers the mechanical variability of root strength due to root material properties, root geometry, and soil mechanical conditions.

The RBMw allows the calculation of root reinforcement in terms of force and displacement for different root distributions which are spatially distributed at the hillslope scale. Such an approach allows an upscaling of root reinforcement in order to quantify the mechanism of slope stabilisation due to plant roots. Schwarz et al. (2010a) showed how root distribution is influenced by the forest structure and how it is possible to quantify root reinforcement as a function of forest structure (tree stem density and dimensions).

The impetus for this work focuses on linking research results to the needs of practitioners by providing supporting evidence to enable quantitative guidelines for planning and evaluation of ground bioengineering stabilisation measures to be formulated, as well as balancing the positive effect of slope stabilisation and carbon storage with the negative effect on pasture production. Available root distribution data provide the necessary foundation to calculate how factors such as location and morphology influence the stabilising effects of vegetation through root reinforcement. In this specific case, root distribution data and mechanical parameters of roots are combined to characterise the dynamic and the spatial distribution of root reinforcement at the slope scale. Root distribution data are rare and difficult to obtain. The comparison of data from two different datasets, as presented in this work, provides a rare opportunity to discuss the effect of environmental conditions and measuring methods on the results of root distribution.

The objectives of this paper are to characterise the lateral root distribution of poplar trees using datasets from two different locations in order to compare the influence of environmental conditions, calibrate the root distribution model from Schwarz et al. (2010a), and calculate the spatial distribution of root reinforcement on slopes with different tree spacing. Finally, it was also the aim to simulate the stabilisation effects of root reinforcement on slopes prone to failure in order to formulate general guidelines for planning and evaluation of ground bioengineering stabilisation measures.

\section{Methods}

\section{General modelling process}

Detailed root distribution datasets were used to calibrate the root-distribution model proposed by Schwarz et al. (2010a) and then combined with the mechanical parameterisation of root reinforcement implemented using unpublished $^{1}$ and published data for New Zealand poplars (McIvor et al. 2011). The results of the model simulations using different combinations of parameter values, tree density, and tree dimension were then used to quantify the minimum planting setup needed to assure minimum levels of lateral root reinforcement $(2,5,10$, and $15 \mathrm{kPa}$, respectively). Finally, a three-dimensional force-balance approach was used to calculate the lateral root reinforcement needed for hillslope stabilisation as a function of slope inclination and mechanical properties of soil, as illustrated by Schwarz et al. (2010a). The details of the applied methods are explained in the following sections.

\section{Study area and data collection}

Datasets of poplar root distribution from two localities were used for calibrating the root distribution model:

- The Gisborne Dataset, G, is from measurements of two single, but complete, root systems of poplar (Populus deltoides Marshall x P. nigra L. clone 'Veronese') trees grown from poles: one tree aged 1 year and one tree aged 2 years. Trees were part of a field trial established in September 2009 near Gisborne on the east coast of the North Island (see Phillips et al. 2014 for details). The trial was established on a low-lying, even-surfaced alluvial flat terrace adjacent to the Taraheru River, at the site of previous 'plant growth performance' trials to allow comparisons between species (e.g. Marden et al., 2005). The soil is a free draining 'Te Hapara' Typic Sandy Brown Soil (Hewitt, 1998). The site (50 m by $50 \mathrm{~m}$ ) was tilled before planting, weed mat laid to reduce competition from weeds, and trickle irrigation installed (to deal with summer dry periods). Poles (3 $\mathrm{m}$ un-rooted stem cuttings approximately 50-60 $\mathrm{mm}$ in diameter at the base) were pushed/ rammed vertically into the soil to $0.7 \mathrm{~m}$ depth on a $5 \mathrm{~m} \times 5 \mathrm{~m}$ grid. Root distribution was measured by the complete excavation of the root systems. The number and the dimension of roots were measured along regularly spaced concentric circles centred on the middle of the stem $(0.5,1.5,2.5,3.5, \ldots m)$. Root 
diameters were measured manually with a pair of callipers. The number of roots was calculated for root diameter classes of $1 \mathrm{~mm}$ interval $(0-1.5,1.6-$ $2.5,2.6-3.5, \ldots)$. Fine roots are defined as having a diameter less than $1.5 \mathrm{~mm}$.

- The Palmerston North Dataset, PN (3 m poplar poles, densities 89, 160, 210, and 237 stems per hectare (sph)). This dataset was obtained from a study on the effect of tree density on root distribution of hybrid poplar (Populus deltoides Marshall x P. nigra L. clones 'Veronese' and 'Tasman') growing on two nearby ( $<1 \mathrm{~km}$ apart) pastoral hill country sites at AgResearch's Ballantrae Hill Country Research Station near Palmerston North (Douglas et al. 2010). Plantings at the two sites were on slope angles of $0-30^{\circ}$ but most were on angles of $5-20^{\circ}$. Soils were silt loams with limited natural drainage, grey subsoil, and various mottles and concretions. The trees were aged 9-11 years, and most were arranged in a Nelder radial planting design established in 1996. Maximum average tree height was $15.2 \mathrm{~m}$, and mean diameter at breast height (DBH; $1.4 \mathrm{~m}$ above ground on the upslope side of trees) ranged from 0.17 to $0.30 \mathrm{~m}$. Roots between adjacent trees at densities of 89 (10.6 $\mathrm{m} \times$ $10.6 \mathrm{~m}), 160(7.9 \mathrm{~m} \times 7.9 \mathrm{~m}), 210(6.9 \mathrm{~m} \times 6.9 \mathrm{~m})$, and $237(6.5 \mathrm{~m} \times 6.5 \mathrm{~m}) \mathrm{sph}$ were assessed in trenches to determine root number and root diameter distribution. A total of 20 trenches were analysed in this study, 5 for each tree density (89, 160, 210, and $237 \mathrm{sph}$ ). Each trench was $1.2 \mathrm{~m}$ long, $1.0 \mathrm{~m}$ deep, and $0.4 \mathrm{~m}$ wide, and measurements were made by placing a $0.9 \mathrm{~m} \times 0.9 \mathrm{~m}$ steel reinforcing mesh on the smoothed trench faces. The mesh comprised 36 cells, each $0.15 \mathrm{~m} \times 0.15 \mathrm{~m}$, arranged in six rows of six cells per row. The number and dimension of roots were collected for each cell. Root diameters were measured manually using a pair of callipers. The technique measured roots growing horizontally or at an angle to the trench face and excluded roots growing vertically (tap roots, sinker roots). The minimum distance of trench faces from trees was $0.9 \mathrm{~m}$ so that information on roots in close proximity to the original planting pole was not recorded. The values used as input for the model simulations for the two datasets are summarised in Table 1.

\section{Root distribution modelling}

The root distribution data were used to calibrate the root distribution model described by Schwarz et al. (2010b). This modelling approach involves a static fractal-branching model (Tobin et al. 2007) based on simple morphogenetic parameters, similar to those used by other models (Diggle
Table 1 Data inputs for the root-distribution model (DBH and distance of each tree, $T$, from each soil trench, $P$ ), in the four transects (89, 160, 210, and 237 sph) (also see Fig. 4)

\begin{tabular}{|c|c|c|c|c|c|c|}
\hline \multirow[t]{2}{*}{$\begin{array}{l}\text { Tree number and } \\
\text { spacing }\end{array}$} & \multirow[t]{2}{*}{$\begin{array}{l}\text { DBH } \\
(\mathrm{m})\end{array}$} & \multirow[b]{2}{*}{ P1 } & \multirow[b]{2}{*}{ P2 } & \multicolumn{2}{|l|}{$\begin{array}{l}\text { Distance } \\
(\mathrm{m})\end{array}$} & \multirow[b]{2}{*}{ P5 } \\
\hline & & & & P3 & P4 & \\
\hline \multicolumn{7}{|l|}{$89 \mathrm{sph}$} \\
\hline T1 & 0.19 & 5.35 & 13.4 & 16.1 & 18.8 & 26.7 \\
\hline T2 & 0.26 & 5.35 & 2.7 & 5.4 & 8.1 & 16.0 \\
\hline T3 & 0.26 & 16.15 & 8.1 & 5.4 & 2.7 & 5.2 \\
\hline T4 & 0.2 & 26.55 & 18.5 & 15.8 & 13.1 & 5.2 \\
\hline \multicolumn{7}{|l|}{$160 \mathrm{sph}$} \\
\hline T1 & 0.27 & 3.75 & 9.55 & 11.60 & 13.65 & 19.77 \\
\hline $\mathrm{T} 2$ & 0.29 & 3.75 & 2.05 & 4.10 & 6.15 & 12.27 \\
\hline T3 & 0.25 & 11.95 & 6.15 & 4.10 & 2.05 & 4.07 \\
\hline T4 & 0.22 & 20.1 & 14.30 & 12.25 & 10.2 & 4.07 \\
\hline \multicolumn{7}{|l|}{$210 \mathrm{sph}$} \\
\hline T1 & 0.31 & 3.35 & 8.45 & 10.2 & 11.95 & 17.2 \\
\hline $\mathrm{T} 2$ & 0.31 & 3.35 & 1.75 & 3.5 & 5.25 & 10.5 \\
\hline T3 & 0.31 & 10.35 & 5.25 & 3.5 & 1.75 & 3.5 \\
\hline T4 & 0.28 & 17.35 & 12.25 & 10.5 & 8.75 & 3.5 \\
\hline \multicolumn{7}{|l|}{$237 \mathrm{sph}$} \\
\hline $\mathrm{T} 1$ & 0.26 & 3.05 & 7.77 & 9.45 & 11.12 & 16.15 \\
\hline $\mathrm{T} 2$ & 0.3 & 3.05 & 1.67 & 3.35 & 5.02 & 10.05 \\
\hline T3 & 0.23 & 9.75 & 5.02 & 3.35 & 1.67 & 3.35 \\
\hline $\mathrm{T} 4$ & 0.21 & 16.15 & 11.72 & 10.05 & 8.37 & 3.35 \\
\hline
\end{tabular}

1988; Lynch et al. 1997; Ozier-Lafontaine et al. 1999; Pages et al. 2004).

The starting point for modelling root distribution requires information on the fine-root $(<1.5 \mathrm{~mm}$ diameter) distribution. The distribution of root diameters associated with primary and secondary root systems is assumed to be strongly correlated with mean fine-root distribution and distance from the tree stem. The total number of fine roots $\left(N_{\mathrm{fr}}\right)$ in a root system associated with an individual tree may be estimated from the sapwood area, crown volume, or other tree properties (Schwarz et al. 2010b). In the following calculations, the DBH of the tree is used applying the equation

$$
N_{\mathrm{fr}}=\mu\left(\frac{\mathrm{DBH}}{2}\right)^{2}
$$

where $\mu$ is the empirical pipe coefficient $\left(\mathrm{N}^{\circ} \mathrm{m}^{-2}\right)$ and $\mathrm{DBH}$ is the tree stem diameter at $1.4 \mathrm{~m}$ height $(\mathrm{m})$.

Additionally, the maximum lateral (radial) extent of a root system $\left(d_{\text {stem max }}\right)$ may be estimated using empirical relationships such as proposed by Roering et al. (2003) and Ammer and Wagner (2005) with the form 


$$
d_{\text {stem } \max }=\delta \mathrm{DBH}
$$

where $\delta$ is a dimensionless empirical coefficient.

The calculation of the fine-root density as a function of distance from tree stem has the form

$$
D_{\mathrm{fr}}=S\left(d_{\text {stem }}\right) \frac{\frac{N_{\mathrm{fr}}}{d_{\text {stem }}}}{\left(2 \pi d_{\text {stem }}\right)} \frac{d_{\text {stem } \max }-d_{\text {stem }}}{d_{\text {stem } \max }}
$$

where $d_{\text {stem }}$ is the distance from tree stem $(\mathrm{m})$ and $S\left(d_{\text {stem }}\right)$ is a survival function

$$
S\left(d_{\text {stem }}\right)=1-\left(\exp \left(-\left(\frac{\left(d_{\text {stem }}\right)}{d_{\text {frf }} \cdot \mathrm{DBH}}\right)^{w}\right)\right)
$$

where $d_{\text {frf }}$ is a dimensionless factor for the estimation of the scaling factor of the survival function $\left(=d_{\text {frf }}\right.$. $\mathrm{DBH})$, and $w$ is the shape factor of the survival function.

The density of coarse roots as a function of distance from the stem is deduced by assuming a constant value of branching distance (BD) (Ozier-Lafontaine et al. 1999; Van Noordwijk and de Willigen 1994). At each branching point, a coarse root may split into smaller diameter roots, maintaining a constant proportionality factor (red_coeff) between pre-branching cross-sectional areas of a coarse root and the sum of cross-sectional areas of finer roots after branching (Van Noordwijk and de Willigen 1994; Wang et al. 2006). For a given maximum lateral root system extent and for a given fine-root density, the diameter of coarse roots at each branching point is computed defining root diameter as a function of the distance from the stem. Hence, for each distance from a tree, a maximum root diameter (RDmax) is computed as an upper bound for root diameter distribution. The number of roots as a function of root diameter for diameter values between fine-root size and maximum diameter is calculated on the basis of empirical root distribution data using an exponential function (parameter exp_distr) (see Schwarz et al. 2010b).

Calibration of the model was conducted by maximising the likelihood value obtained by the sum of normal probability function of the residuals (mean $=0$ and standard_deviation $\left.=(\text { error variance })^{\wedge}(0.5)\right)$.

\section{Scaling root reinforcement}

Root reinforcement at the hillslope scale is estimated assuming the minimum value of tensile forces calculated for the bundles of roots between neighbouring trees. The tensile forces of the root bundles are calculated using the RBMw (Schwarz et al. 2013). The RBMw requires a set of parameters to quantify the mechanical behaviour of roots and a set of root distribution data (as the results of measurements or modelling, as shown in the previous section).
The mechanical behaviour of each class of root diameter is calculated using the equation of elasticity theory where maximum tensile force and Young's modulus are functions of the root diameter. The failure of roots approaching a critical value of maximum tensile force (breakage or slip-out) is calculated using a survival function. The form of the survival function (in our case a Weibull function) is used to characterise the variability of the root mechanical properties.

Tensile test data obtained for 123 root samples from 'Veronese' poplar trees aged $<10$ years (unpublished data $^{1}$ partially reported in McIvor et al. 2011) were used to calibrate the parameters for estimating the maximum tensile force $(F$, in $[N])$ of each root diameter class. The under-bark diameter of the tested roots ranged from 0.9 to $8.51 \mathrm{~mm}$. Data presented by Hathaway and Penny (1975) are consistent with the above indicating that the following force-diameter equation can be used

$$
F=50 \cdot d^{1.51}[N]
$$

where $d$ is under-bark root diameter $(\mathrm{mm})$. In order to account for the root diameter under-bark used by Watson et al. ${ }^{1}$ and the root diameter with bark considered in the datasets $\mathrm{G}$ and $\mathrm{PN}$, the conversion proposed by Watson et al. ${ }^{1}$ was used (under_bark_diameter $=0.72$ diameter_with_bark $\left.-0.35 ; R^{2}=0.95\right)$. No data for the calibration of the secant Young's modulus equation and the breaking survival function were found for the implementation in the RBMw so the values reported by Schwarz et al. (2013) were used.

The spatial distribution of root reinforcement is characterised in terms of maximum tensile force of the root bundle crossing $1 \mathrm{~m}$ of landslide scarp.

\section{Slope stability calculations}

Calculations of slope stability are made within the limit equilibrium framework considering a unique slice corresponding to the dimensions of the considered shallow landslide. The equilibrium of forces is calculated considering the three-dimensional shape of the shallow landslide (Schwarz et al. 2010a). The shear strength at the failure surface of the shallow landslide was quantified using the Mohr-Coulomb criterion. The inclusion of lateral root reinforcement in slope stability calculations is achieved by considering an additional stabilising force proportional to the upper scarp length and to the lateral root reinforcement calculated for a defined tree density (Schwarz et al. 2010a). In order to compare the efficiency of the lateral root reinforcement versus the basal root reinforcement (Schwarz et al. 2014), $10 \%$ of the lateral root reinforcement was considered in the calculations acting on the landslide slip surface. The value of $10 \%$ is obtained considering the reviewed data of vertical root 
distribution reported by Glenz (2005) and Phillips et al. (2014).

Additionally, the force balance for different landslide dimensions was computed assuming a three-parameter inverse-gamma distribution of the landslide frequencymagnitude distribution proposed by Malamud et al. (2004) with the form

$$
p\left(A_{L} ; \mathrm{\varrho}, a, s\right)=\frac{1}{a \Gamma(\mathrm{\varrho})}\left[\frac{a}{A_{L}-s}\right]^{\mathrm{Q}+1} \exp \left[-\frac{a}{A_{L}-s}\right]
$$

where $A_{\mathrm{L}}$ is the landslide area $\left[\mathrm{km}^{2}\right], \varrho$ is the parameter primarily controlling power-law decay for medium and large values in the three-parameter inverse-gamma probability distribution, $a$ is the parameter primarily controlling location of the maximum in the threeparameter inverse-gamma probability distribution, $s$ is the parameter primarily controlling exponential rollover for small values in the three-parameter inverse-gamma probability distribution, and $\Gamma(\varrho)$ is the gamma function of $\varrho$. The set of parameters fitted by Malamud et al. (2004) $\left(\varrho=1.4, a=1.2810^{-3}\right.$, and $\left.s=-1.3210^{-4}\right)$ was applied, and a sample of 10,000 hypothetical landslides generated using a random number generator function in the R environment (www.r-project.org ).

Variability of soil depth, soil effective friction angle, and soil cohesion were considered assuming a normal distribution. For simplicity, fully saturated conditions were assumed representative of an extreme triggering rainfall event (i.e. pore water pressure $=$ soil depth). Assuming saturated conditions of the soil trench implies that possible additional suction stress due to capillary forces are not present, soil specific weight for fully saturated conditions are considered, and that effective normal stress is given by the normal stress minus the pore water pressure at the shear surface (which is proportional to the soil depth). Based on inventories of shallow landslides (De Rose et al. 1995; Rickli and Graf 2009 ), the mean soil depth was set to $1.2 \mathrm{~m}$ with a standard deviation of $0.1 \mathrm{~m}$. The range of soil mechanical parameters and their variability were estimated according to data reported by Claessens et al. (2007), assuming the values to be normally distributed. Three classes of effective friction angles and cohesion were defined $\left(24^{\circ}, 29^{\circ}\right.$, and $34^{\circ}$ for the friction angle and 0,6 , and $12 \mathrm{kPa}$ for the soil effective cohesion). Soil density was fixed to 1.4 $\left[\mathrm{t} \mathrm{m}^{-3}\right]$ (Claessens et al. 2007). In order to confine the analysis of sediment balance only to shallow landslides (defined as landslides with maximum soil thickness equal to $2 \mathrm{~m}$ ), the relationship found by Kaldaron-Asael et al. (2008) was used to estimate the threshold of maximum shallow landslide area. Assuming a coefficient of 0.03, a threshold of about $5000 \mathrm{~m}^{2}$ was obtained. Based on the event analysis of Rickli and Graf (2009), an elliptical shape of the landslides is assumed with a width/length relationship equal to 0.5 .

The approach described above is essentially the basis of the SlideforNET tool, which was developed to quantitatively assess the effect of lateral root reinforcement on shallow slope stability. The detailed description of this formulation can be found in Schwarz et al. (2010a, 2012b, 2014).

\section{Results}

\section{Root distribution}

\section{Calibration with the $G$ dataset}

Following the procedure described above, the first step consisted of fitting the fine-root distribution. The results of the model calibration for the 1-year-old $(\mathrm{DBH}=$ $66 \mathrm{~mm})$ and the 2 year-old $(\mathrm{DBH}=151 \mathrm{~mm})$ poplar trees are shown in Fig. 2a, b, respectively. The value of variance that maximises the likelihood function is 0.17 and 0.08 . The maximum number of fine roots is between 5 and 6 per metre width of soil trench at a distance that is $1-1.5$ times the $\mathrm{DBH}$. Maximum rooting depth is found to be less than $0.9 \mathrm{~m}$.

The number of fine roots per linear metre is used in the model as an input parameter for calculating the root distribution at different distances from the tree stem. The measured root distribution (points) of the 1-yearold and 2-year-old trees are shown in Fig. 3a-c, respectively. All the simulated data were obtained using a single set of calibrated parameters for the $G$ site reported in Table 2. The decay exponent of the model was calibrated to be equal to -0.5 .

\section{Calibration with the PN dataset}

The results of the calibration of the root distribution model using the PN dataset are shown in Fig. 4. Fineroot distribution for four planting densities could be fitted by the model using a single value of each parameter (independently from tree density and distance from tree). The distribution of fine roots in the 89 and 160 sph densities shows an exponential decay with increasing distance from tree stem, whereas in the 210 and $237 \mathrm{sph}$ densities, a lower variation of fine-root density may indicate overlapping of the root systems of neighbouring trees, as shown in Schwarz et al. (2012a). The results show that the maximum root diameter present in a bundle decreases with increasing distance from the stem. Comparison of trench P1 with P2 shows how maximum root diameter at one quarter of the distance between stems is coarser than at half the distance between stems. The differences between the distribution of P1, P3, and P5 (same distances) show the influence of small difference in distances and stem dimensions on the root distribution. For example, the number of roots is higher for P1 than P2 at 237 sph density, where T1 


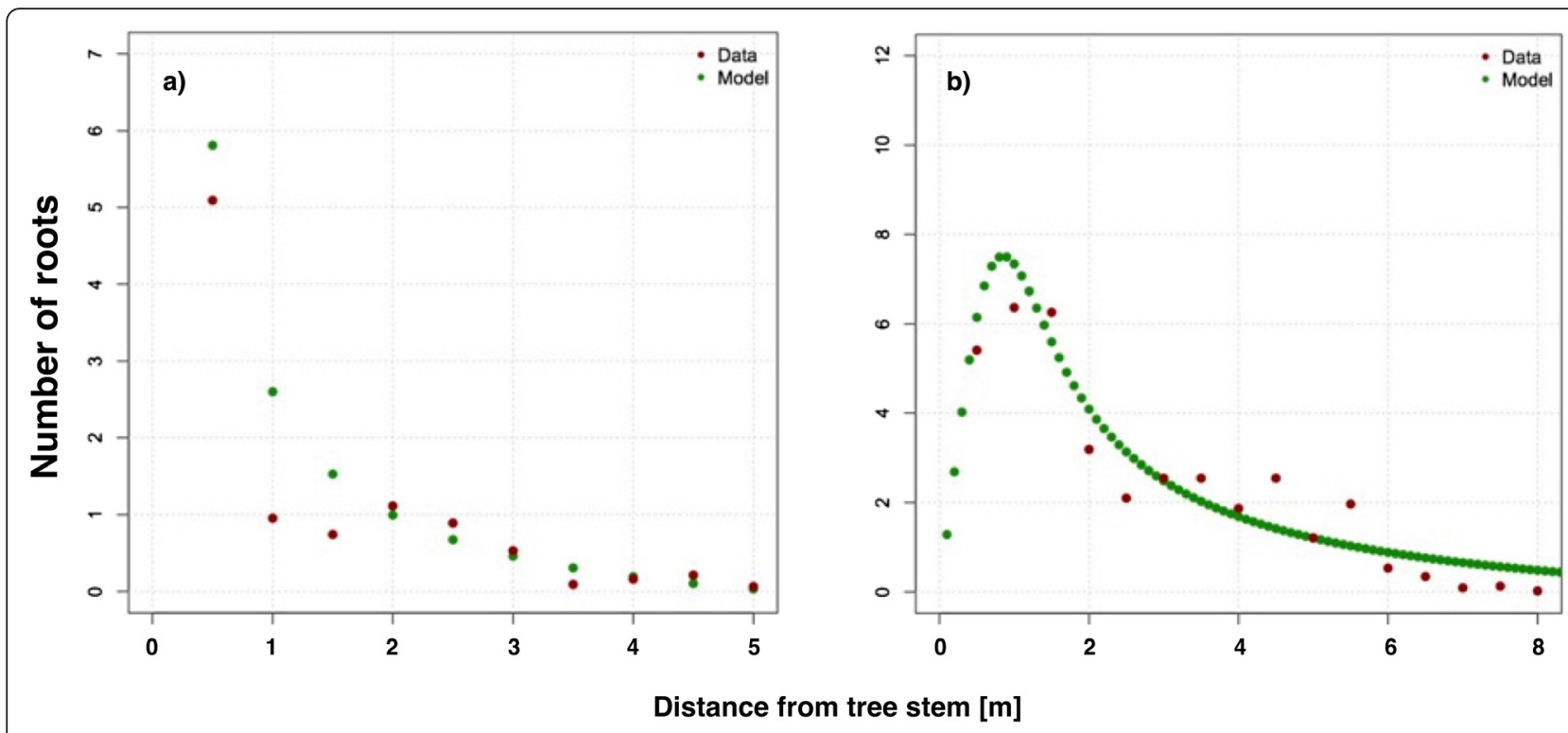

Fig. 2 Number of fine roots per linear metre of soil trench width (along the circumference at a certain distance from tree stem) as a function of the distance from tree stem for the 1-year-old (a) and the 2-year-old (b) poplars. The dark red points are measured data and the green points represent the values obtained with the calibrated root distribution model

and T2 have higher stem dimensions and lower distances than T3 and T4 (see Table 1).

The calibrated values of the model parameters for the two datasets are summarised in Table 2. The two datasets exhibit considerable differences with the pipe coefficient, the root distribution exponent, and the maximum root spread coefficient in particular.

\section{Root reinforcement}

The modelled root distribution results are used to calculate the root reinforcement for different combinations of tree dimensions and distances from tree stem. The calculated distribution of root reinforcement as a function of distance from tree stems of four stem diameters $(0.15,0.2,0.25$, and $0.3 \mathrm{~m} \mathrm{DBH}$ ) is shown in Fig. 5. For each modelled root distribution, the force-displacement behaviour of the root bundle was calculated under tension, and the maximum value of force was used to characterise the lateral root reinforcement. The obtained root reinforcement ranged between 0 (small DBH and large distances) and $30 \mathrm{kN} \mathrm{m}^{-1}$ (0.3 $\mathrm{m} \mathrm{DBH}$ and $2 \mathrm{~m}$ distance). Reinforcement increased with increasing $\mathrm{DBH}$ and decreases with increasing distance from the tree. However, the results obtained by running the model with different calibration datasets were considerably different, i.e. the root reinforcement calculated for the G dataset was greater than from the PN dataset,
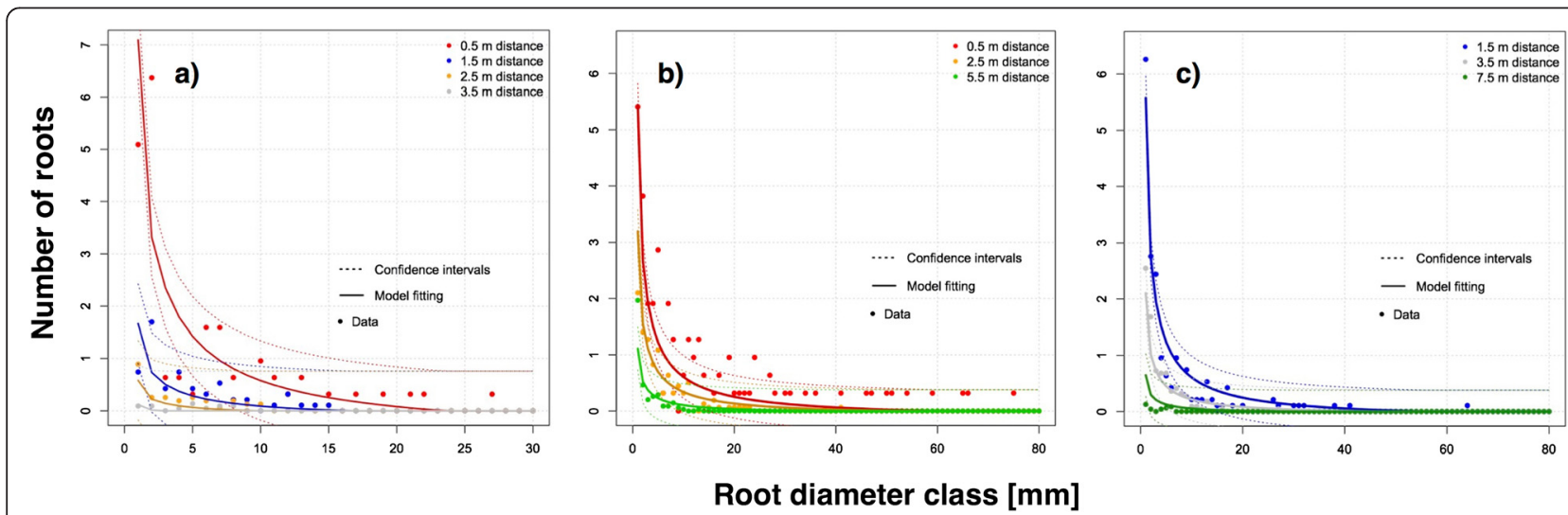

Fig. 3 Root distribution curves at different distances from the tree stem and model calibration results. Points indicate measurements, and coloured lines show the results of the calibrated model: a 1-year-old poplar; $\mathbf{b}, \mathbf{c}$ 2-year-old poplar (the data in $\mathbf{b}$ and $\mathbf{c}$ were split to allow a better visualisation of the data). Dashed lines show the $95 \%$ confidence interval of the model results. The number of fine roots is given per linear metre of soil trench width 
Table 2 Values of the fitted parameters of the root distribution model for the two trees of the $G$ trial and all the trenchs of the PN trial

\begin{tabular}{llll}
\hline Parameter & $\begin{array}{l}\text { Pole }(1 \text { year } \\
\text { old) }\end{array}$ & $\begin{array}{l}\text { Pole (2 years } \\
\text { old })\end{array}$ & Trench \\
\hline $\begin{array}{l}\text { Pipe coefficient (pipe_coef) } \\
\begin{array}{l}\text { Exponent coarse root } \\
\text { distribution (exp_distr) }\end{array}\end{array}$ & 0.029 & 0.045 & 0.077 \\
$\begin{array}{l}\text { Distance peak fine } \\
\text { root frequency (d_frf) }\end{array}$ & -0.5 & -0.49 & -1.38 \\
$\begin{array}{l}\text { Weibull coef. for fine root } \\
\text { distribution (w.coef) }\end{array}$ & 2.5 & 2.1 & 6.4 \\
$\begin{array}{l}\text { Coarse root proportionality } \\
\text { factor (red_coef) }\end{array}$ & 2.5 & 2.1 & 6.2 \\
$\begin{array}{l}\text { Maximum root spread } \\
\text { coefficient (max_dist_coef) }\end{array}$ & 74 & 88 & 0.18 \\
\begin{tabular}{l} 
Error variance (var) \\
\hline
\end{tabular} & 0.17 & 0.08 & 14 \\
\hline
\end{tabular}

reflecting the differences in root distribution at the two sites.

Calculated root reinforcement using measured and modelled root distribution of the PN datasets were compared in order to analyse the effect of the interaction between neighbouring root systems on the distribution of root reinforcement. The results showed that root reinforcement increased with increasing stem density per hectare (from red points/lines to orange points/lines in Fig. 6) for both modelled and measured root distributions. The three values of reinforcement obtained for the middle distance between trees $(0.5,1.5,2.5$ normalised distances) follow similar trends, whereas the results at 1.25 and 1.75 normalised distances show inverse trends with higher root reinforcement for the $160 \mathrm{sph}$ than the 210 and $237 \mathrm{sph}$. The normalised distance is defined as the quotient between the position of the considered soil trench and the distance to the tree stems.

Using the calibrated root distribution model, threshold values of minimum root reinforcement $(2,5,10$, and $15 \mathrm{~N} \mathrm{~m}^{-1}$ ) were then able to be calculated considering different combinations of stems per hectare and mean stem DBH at stand scale. The calculated minimum distances between stems needed in order to obtain the desired minimum level of lateral root reinforcement ( $\mathrm{kN}$ per linear metre along the potential landslide scarp) are shown in Fig. 7. In order to calculate the corresponding number of stems per hectare needed to reach a defined threshold of root reinforcement, the surface of one hectare must be divided by the distance between stems (dis) elevated to the square $\left(\mathrm{sph}=10,000 \mathrm{dis}^{-2}\right)$.

In order to assess the influence of the considered thresholds of lateral root reinforcement on the stability of the slope, the 'Slidefor ${ }^{N E T}$ ' tool (www.ecorisq.org, Switzerland) was applied to different combinations of slope inclination $\left(24^{\circ}, 29^{\circ}\right.$, and $\left.34^{\circ}\right)$, soil friction angle $\left(\left(24^{\circ}, 29^{\circ}\right.\right.$, and $\left.34^{\circ}\right)$, and root reinforcement $(0,2,5,10$, and $\left.15 \mathrm{kN} \mathrm{m}^{-1}\right)$. The results indicate that the most consistent variation in frequency-magnitude was obtained for landslide areas up to $2000 \mathrm{~m}^{2}$ (Fig. 8).

In order to test the sensitivity of the slope stability calculations as functions of the slope inclination $(\beta)$, soil effective internal friction angle $\left(\Phi^{\prime}\right)$, and soil effective cohesion ( $\left.c^{\prime}\right)$, a series of simulations were performed using $24^{\circ}<\beta<34^{\circ}, \quad 24^{\circ}<\Phi^{\prime}<34^{\circ}, \quad 0<\mathrm{c}^{\prime}<$ $12 \mathrm{kPa}$ and a fixed set of parameters. Changes in total normalised landslide volume as a function of lateral root reinforcement considering three classes of soil cohesion are shown in Fig. 9. The normalised landslide volume is defined as the quotient between the sum of landslide volumes calculated considering a minimum value of lateral root reinforcement and the sum of landslide volume calculated considering zero lateral root reinforcement. Generally, the potential landslide volume decreased with increasing lateral root reinforcement (Fig. 9), as might be expected. The effectiveness of lateral roots for stabilising slopes increased with decreasing slope inclination. In the case of zero soil cohesion, the reduction of normalised landslide volume reached $65 \%$ for a $15 \mathrm{kN} \mathrm{m}^{-1}$ of lateral root reinforcement, $24^{\circ}$ slope inclination, and $34^{\circ}$ of soil effective friction angle. In the case of slope inclination of $34^{\circ}$ with soil effective friction angle of $24^{\circ}$, the effect of lateral root reinforcement was negligible. However, assuming that the depth of potential failure surfaces could be located within the rooting zone on steep slopes, then it may be assumed that some root reinforcement is acting on the shear surface. These results show that basal root reinforcement increases the stability of areas that may potentially suffer from landslides (Fig. 9).

\section{Discussion \\ Root distribution and reinforcement}

Differences in measured root distribution in the two datasets ( $\mathrm{G}$ and $\mathrm{PN}$ ) analysed may be due to a range of factors. Phillips et al. (2014) found that root growth rate at the $G$ trial site was greater than that reported in comparable studies reported in the literature, arguing that the uniform sandy loam alluvial soil, warm temperatures, available moisture, and weed suppression were all factors likely to have contributed to particularly favourable root growing conditions. In contrast, the denser, clay-rich, heterogeneous soils such as those at the PN site may have restricted root growth and performance of trees at that site. The different tree ages at the time of sampling (1-2 years in $\mathrm{G}$ and 9-11 years in PN) represent an issue when comparing data on root distribution. However, in the context of the modelling framework, the physiological-related 


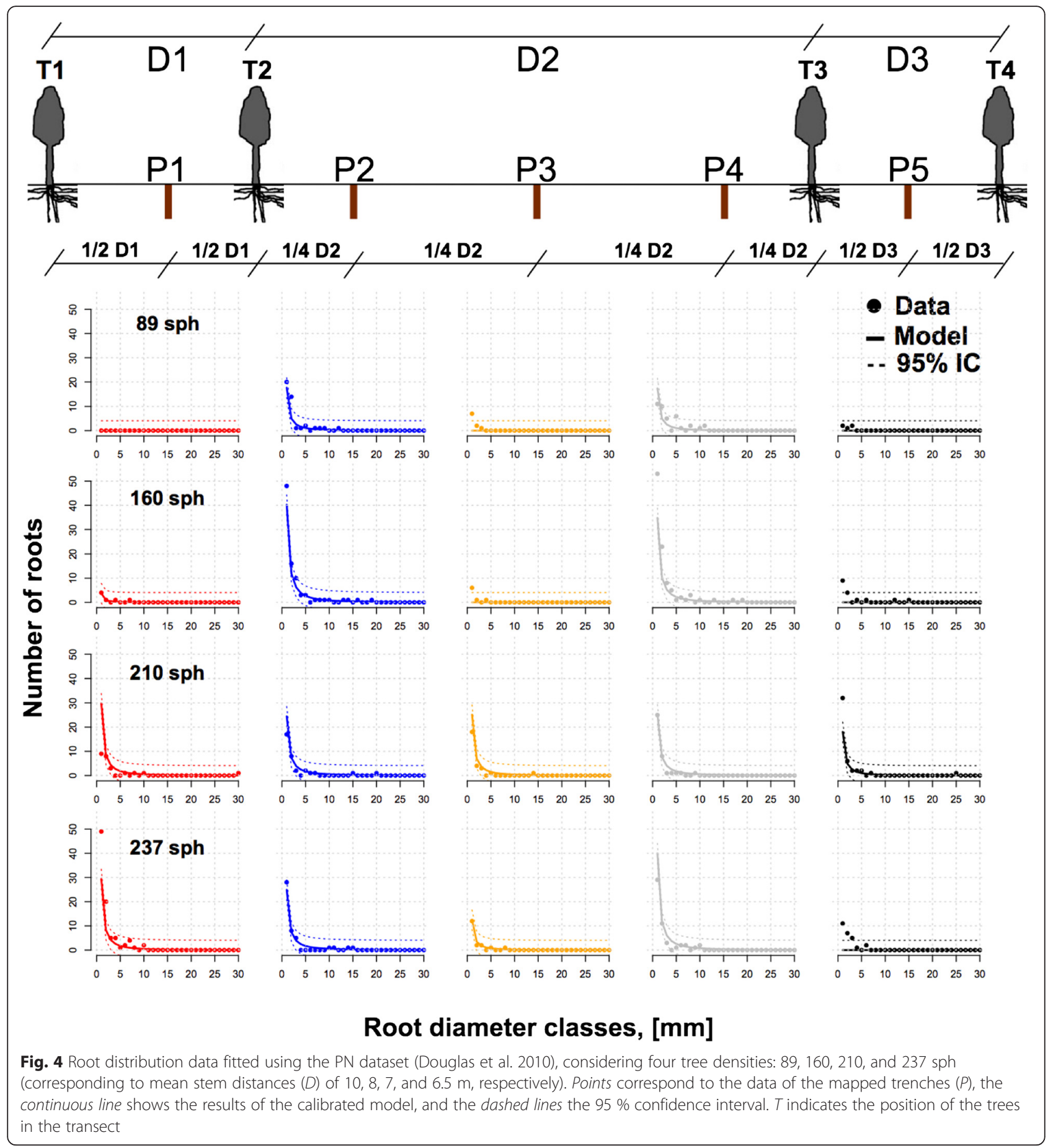

parameters such as the pipe coefficient or maximum rooting distance coefficient represent a useful term of comparison between the growing conditions of the two field sites. Differences in the root distribution within the same field site may be explained by the variability of the initial planting material and local variation of environmental factors. For instance, it is recognised that the size and volume of planting materials influence the initial growth rate of roots and shoots (Phillips et al. 2014, 2015; Sulaiman 2006), due to the effect of rhizocauline (Schiechtl 1992) present in the cambium cells. The higher survival and growth rates of larger diameter poles may compensate for their extra start-up cost during field establishment (Sulaiman, 2006). Another reason for the differences in the root distribution between the two datasets could be related to the different sampling methods used to obtain the field 


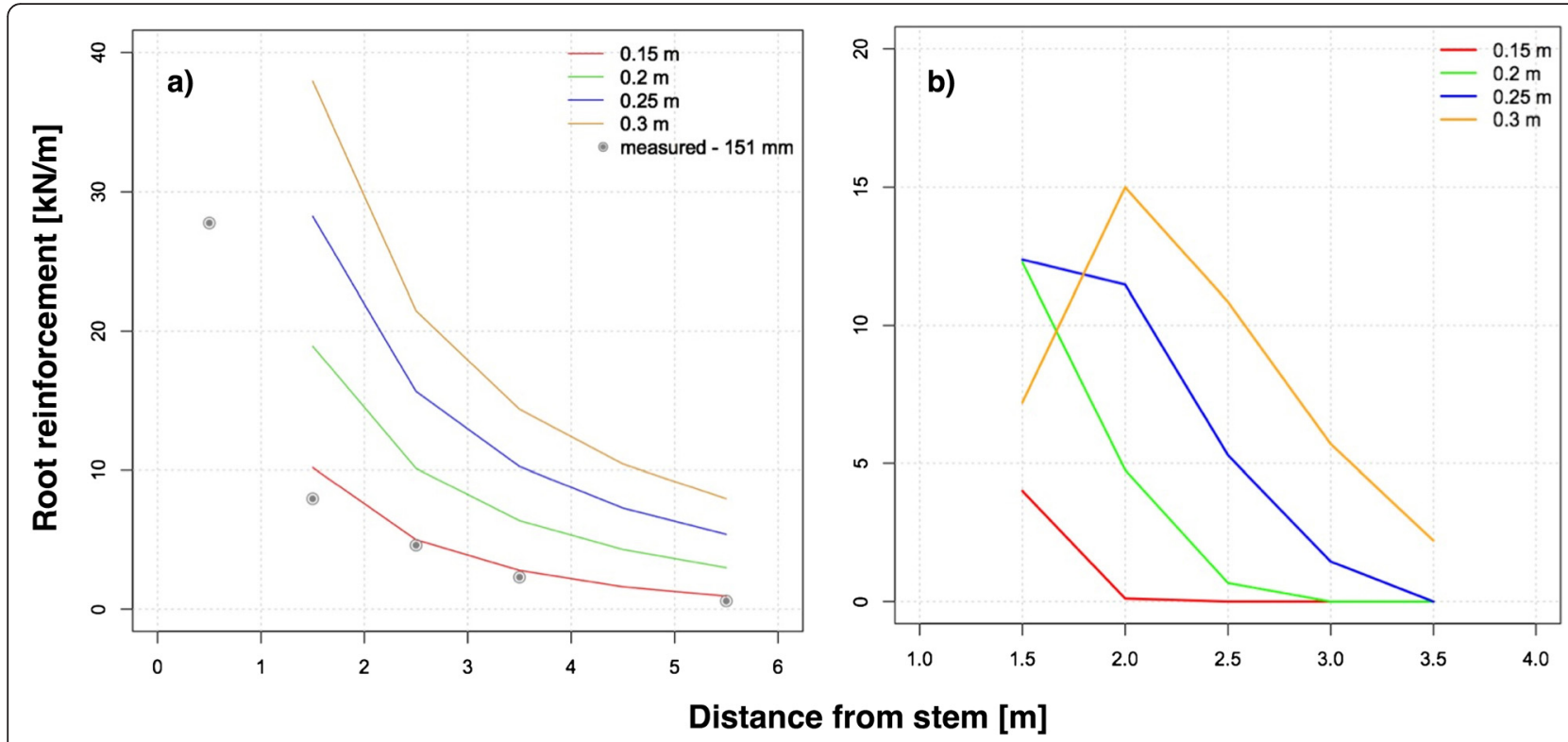

Fig. 5 Maximum root reinforcement as a function of distance from tree stem for stems of different diameters $(0.15,0.2,0.25$, and $0.3 \mathrm{~m}$ DBH) calculated with the RBMw calibrated with the two datasets $\mathbf{a}=$ Gisborne $(\mathrm{G}), \mathbf{b}=$ Palmerston North (PN). The grey dots show the calculated root reinforcement using the measured root distribution of the 2-year-old poplar pole of the $\mathrm{G}$ dataset

data. The time-consuming excavation of entire root systems tends to limit measurements to only a few trees, but the trench sampling used to obtain the PN dataset provides a lower accuracy in terms of spatial characterisation of roots but enables the analysis of variability among more trees. In the case of asymmetrical root systems, the trenching method may lead to underestimation or exaggeration of root number depending on the direction of the trench position. In this study, how the proposed quantitative framework could be applied to both types of datasets has been demonstrated, using either a single tree (e.g. the G dataset) or multiple trees (e.g. the PN dataset) for model calibration. Although comparing the root distribution of the two datasets is difficult because of different field trial characteristics, age of trees, and sampling methods, the application of a modelling framework does allow a general comparison of the datasets in terms of calibrated model parameters. Moreover, the possibility to cross-calibrate the model using the best existing datasets for 'Veronese' poplar allows for some discussion on the variability of root distribution as influenced by environmental conditions.

One of the most important and difficult to measure parameters of a tree's root distribution is the maximum lateral root spread. Only difficult and timeconsuming measurements, as performed for example in the $\mathrm{G}$ dataset, lead to an accurate assessment of the maximal lateral spread of a root system (Phillips et al. 2014). Nevertheless, the results shown in Fig. 4 support the calibrated model coefficient value of 14 (shown in Table 2) for the PN dataset. This number is based on a mean DBH of $0.3 \mathrm{~m}$. From this, a maximum lateral root spread of $4.2 \mathrm{~m}$ was obtained, which

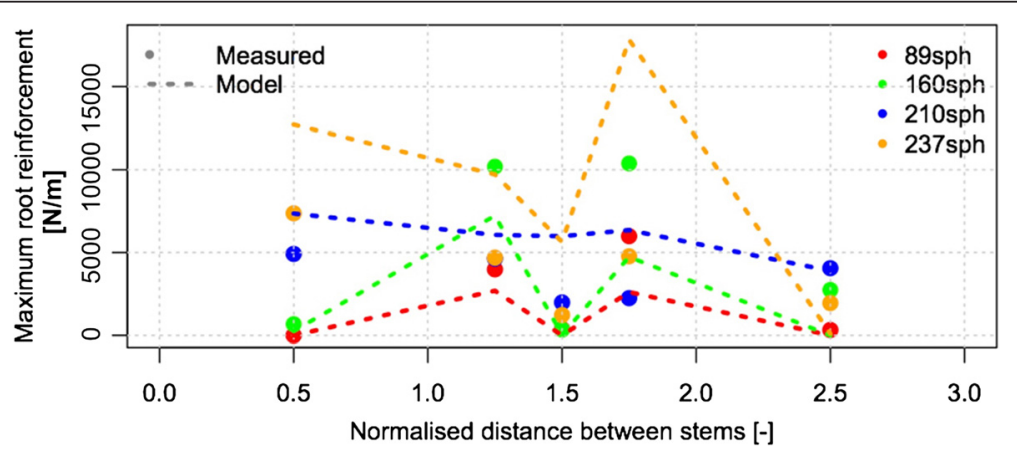

Fig. 6 Distribution of calculated maximum root reinforcement $(\mathrm{kN} / \mathrm{m})$ for the measured (points) and modelled (dashed lines) root distribution of the PN dataset. The colours indicate different stem density per hectare (sph). The positions of the tree stems correspond to normalised distances of $0,1,2$, and 3 


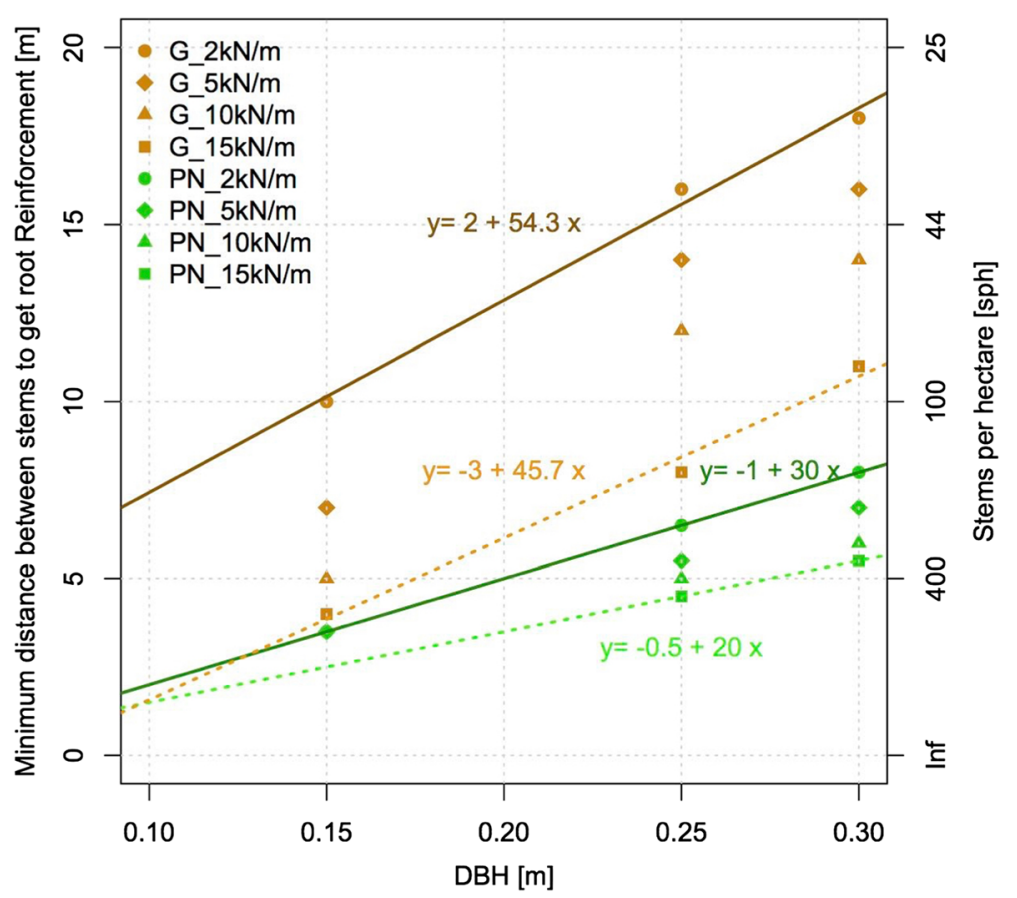

Fig. 7 Relationships between DBH and stem distance obtained for different combinations of root reinforcement class $\left(2,5,10\right.$, and $\left.15 \mathrm{kN} \mathrm{m}^{-1}\right)$ and location ( $G$ and $P N)$. Estimated minimum distance between trees $(\mathrm{m})$, of three stem diameters $(0.1,0.2$, and $0.3 \mathrm{~m} \mathrm{DBH})$, needed to achieve root reinforcement of 2 to $15 \mathrm{kN} \mathrm{m}^{-1}$. Letter $\mathrm{G}$ corresponds to the values calculated for the 'Gisborne' dataset, and PN corresponds to the range of values calculated for the 'Palmerston North' dataset. Values are approximated at $0.5 \mathrm{~m}$

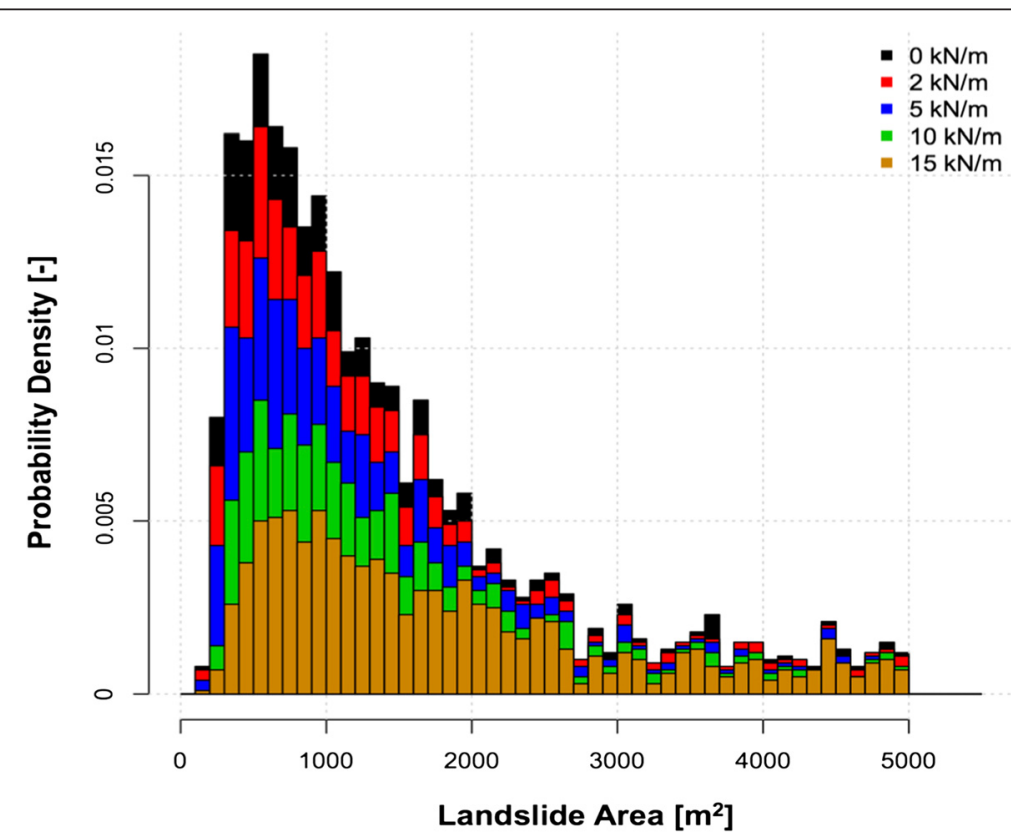

Fig. 8 Frequency-Magnitude distribution of shallow landslides calculated with the Slidefor ${ }^{\text {NET }}$ tool assuming increasing values of lateral root reinforcement (legend). The histogram shows the results of an example calculated for a slope inclination of $24^{\circ}$, a friction angle of $29^{\circ}$, and a soil cohesion of $0.2 \mathrm{kPa}$ 


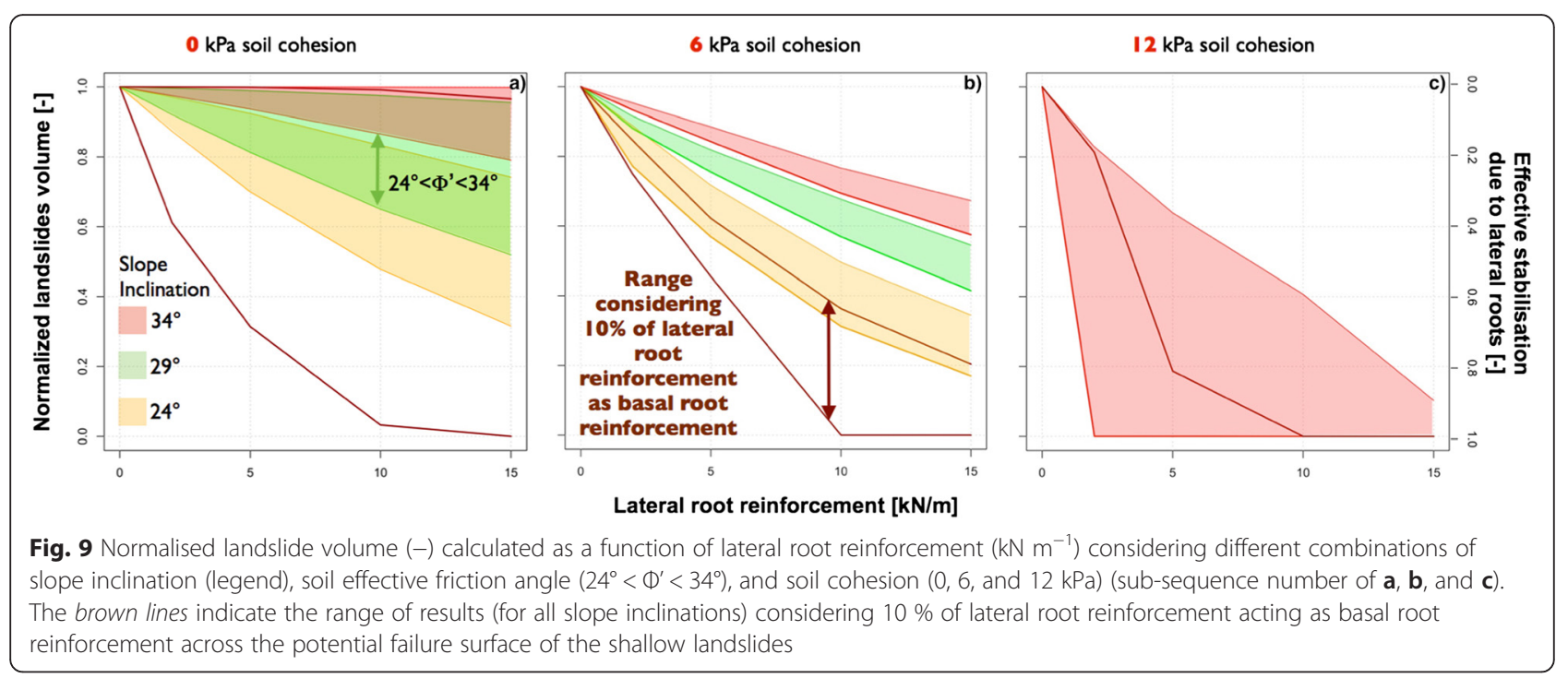

means that no roots are expected to cross soil trenches at the middle distance between trees with density lower than $160 \mathrm{sph}$. Analogously, the calculated maximum lateral root spread of $13.3 \mathrm{~m}$ for the 2 -year-old poplar of the $G$ dataset is comparable to the values reported in Phillips et al. (2014) for growth of another 'Veronese' poplar at the $\mathrm{G}$ field site.

Another difficult parameter to be determined is the pipe coefficient. An exact estimation of this parameter is possible only if all the fine roots of the root system are measured, as in the case of the $\mathrm{G}$ dataset; otherwise, it can be estimated fitting the distribution of fine roots at different distances from the tree stem (as shown in Fig. 4). Not surprisingly, the results of this study show that the estimated pipe coefficient is considerably different for the two datasets. Considering that the pipe coefficient is an index of how many fine roots are actively contributing to metabolism of the plant (assimilating water and nutrients), it could be argued that increased concurrence and unfavourable local stand characteristics (i.e. soil type) would lead to a reduction in metabolism and thus to a reduction in fine-root number and growth. However, the value of the pipe coefficient results is actually higher for the PN dataset than the $\mathrm{G}$ dataset because the total number of fine roots is concentrated in a smaller area occupied by the root system, resulting in low total number of fine roots.

Fitted parameters in the root distribution model such as the 'Exponent of coarse root distribution (exp_distr)' and the 'Coarse root proportionality factor (red_coef)' reflect the characteristics of the coarse roots in terms of frequency and maximum root diameter, respectively. The 'Peak distance of fine root frequency (d_frf)' and 'Weibull coef.' for 'fine-root distribution (w.coef)' parameters were used to characterise the fine-root distribution as a function of distance from tree stem. The range of d_frf values indicated that the maximum density of fine roots was expected at a distance equal to 2 and 6 times the tree $\mathrm{DBH}$ for the $\mathrm{G}$ and $\mathrm{PN}$ datasets, respectively. The importance of fine-root density in determining the magnitude of root bundle tensile strength is shown in Fig. 5 in comparison to the results of Fig. 2b, where the maximum root reinforcement for a tree with $0.3 \mathrm{~m} \mathrm{DBH}$ is expected at about $1.9 \mathrm{~m}$, exactly at the distance where the maximum intensity of fine-root density is reached. Overall, the two sets of parameters calibrated for the G dataset are consistent, showing that the tree stem diameter has a major influence on the different results of root distribution.

Seasonal changes in fine-root frequency may also be an important factor influencing lateral root reinforcement. McIvor et al. (2011) found that 'Veronese' poplar had a significant reduction in fine-root length density during the dormant season, with little change in coarse root distribution observed. From the modelling perspective, it may be assumed that only root diameters greater than $2 \mathrm{~mm}$ contribute to lateral root reinforcement constantly during the year; this assumption may have a strong effect on the estimation of root reinforcement since fine roots in some cases determine the overall mechanical behaviour of the root bundle. For instance, the calculation of lateral root reinforcement for the root distribution measured at trench number 4 (P4) on the $160 \mathrm{sph}$ plot of the PN dataset produced a value of $10.4 \mathrm{kN} \mathrm{m}^{-1}$, whereas assuming zero root for diameter classes $<2 \mathrm{~mm}$, a value of $8.85 \mathrm{kN} \mathrm{m}^{-1}$ lateral root reinforcement was obtained. In this case, the contribution of fine roots to total lateral root reinforcement is relatively small (about $20 \%$ ), but in the case of a root bundle far from the tree stem, this contribution may be higher and lead to values of root reinforcement equal to 0 . 
Root systems on moderate to steep slopes may develop more asymmetric growth patterns than on flat land, particularly in the upslope-downslope direction (Chiatante et al. 2003), depending on factors including species, soil texture, plant age, mechanical effects (wind-snow), and nutrient-water availability (Stokes et al., 2009). A simple overlapping pattern of root systems was used in the calculation of the minimum distance between trees presented in Fig. 7. This simplification excluded the possible effect of root system concurrence and asymmetry due either to hillslope inclination or the concurrence of neighbouring trees. Even if this simplification is unrealistic, it seems that when considering the effective tree distance for slope stabilisation, then the concurrence effects of neighbouring root systems on the root distribution are weak and thus may be excluded (Schwarz et al. 2010b). Also under these conditions, the effects of grafting or mechanical interaction between roots have no influence on the calculation of rootbundle tensile forces, as discussed in Giadrossich et al. (2012). Moreover, in the case of poplar species growing on gentle slopes, no effect of direction of slope was found by McIvor et al. (2005), which is in accord with the assumption made in the model tested here. Further research is needed to clarify these aspects for other locations or other tree species.

The differences in root diameter distribution for the two datasets (G and PN) are reflected in a considerable difference in the distribution of maximum root pullout forces as shown in Fig. 5. Root distribution is an important factor in determining root reinforcement behaviour (maximal pullout forces and stiffness), as well as the mechanical and geometrical properties of roots (Schwarz et al. 2010a; Cohen et al. 2011). Root number as well as the distribution of diameter classes of roots also has a major influence on the mechanical properties of a bundle of roots. The peak of root reinforcement at $2 \mathrm{~m}$ distance from a $0.3 \mathrm{~m} \mathrm{DBH}$ tree modelled for the PN dataset is due to the peak of root frequency calculated for this distance. This result shows that, at this distance, root reinforcement is dominated by roots with diameter classes less than $2 \mathrm{~mm}$. While the number of roots mainly influences the magnitude of the reinforcement, the distribution of roots in different diameter classes influences the magnitude of reinforcement, with a factor ranging from 1 to 3 (Cohen et al., 2011), and the stiffness of the reinforcement (Schwarz et al. 2013). This last aspect has been discussed less often in the literature, but it represents an important factor in conditions where the stabilisation effects of roots are due mainly to lateral roots (Schwarz and Cohen 2011; Schwarz et al. 2012a, Schwarz et al. 2015). Although the results show a good prediction of the root distribution model (Fig. 4), the prediction of root reinforcement in Fig. 6 shows how sensitive this calculation is to slightly different distribution of roots, especially in the case of the PN dataset. Vice versa, the model prediction of root reinforcement based on the G dataset fits the data better (Fig. 5). This difference may be explained by two main reasons. First, the simulation conducted for only a single tree is not a representative of an entire stand and thus shows lower variability. Second, the calibration of the root distribution model based on data of a complete excavated root system with a greater number of trench distances (one every metre) allows for the whole root system to provide a better prediction of root distribution.

The force-diameter relationship is also important because it strongly influences the calculation of root reinforcement using the RBMw. Force-diameter relationships are usually quantified by laboratory tensile tests of root diameters up to a few millimetres, but difficulties exist in extrapolating values for larger root diameters. The unpublished poplar data of Watson et al. ${ }^{1}$ include root diameters up to about $8 \mathrm{~mm}$ (see Additional file 1), which increases the plausibility of results from the $\mathrm{RBMw}$ for a root bundle dominated by roots smaller than $8 \mathrm{~mm}$. The variability of measured root tensile strength is considered in the RBMw using a survival function with a Weibull shape, which describes the probability of a root breaking before or after the fitted value of maximum tensile force (Schwarz et al. 2013). Even if the unpublished force-diameter data of 'Veronese' poplar roots from Watson et al. ${ }^{1}$ used in the calculation were obtained for root material from a different location than PN and G, it was assumed that these data were, on average, representative for the studied field conditions. In fact, it is not possible to make a direct comparison of these data with other data from the literature for the same clone, or even the same species. Further studies are needed to assess the variability of root mechanical properties of poplar, also both as a function of local environmental conditions and of the development stage of the plant. For instance, Hathaway and Penny (1975) discussed how root strength depends on season, showing that the root tensile strength of 1-yearold poplar clone 'I-488' was greater during the winter, reaching a peak in September (early spring), in parallel to a peak in lignin content. In view of such probable root mechanical seasonal variability, the results presented in this study aimed to quantify the possible range of lateral root reinforcement due to 'Veronese' poplar roots only as a function of different root distribution datasets.

\section{Stabilisation effect of lateral root reinforcement and application of results for erosion control}

Rooting depth reported in the literature for 'Veronese' poplar ranges between 0.5 and $1 \mathrm{~m}$, indicating that no basal root reinforcement may be expected in shallow 
landslides with failure surfaces commonly between 1 and $2 \mathrm{~m}$ soil depth. According to Schwarz et al. (2010a), lateral root reinforcement has been shown to contribute to slope stability. The values of estimated lateral root reinforcement in our results confirm the finding of Schwarz et al. (2010a). The use of the 'Slidefor ${ }^{\text {NET' }}$ approach allows for a stochastic characterisation of the effects of lateral root reinforcement on slope stability in terms of reduced partial landslide probability (Fig. 8), or in terms of stabilised landslide volume (Fig. 9).

The stabilisation effects of lateral roots are related to their spatial distribution, which is related to the architecture of each root system and the position of the trees on the slope (inter-tree distance). Interlocking root systems with a high number of roots allow a wider redistribution of destabilising forces, increasing the probability that unstable zones are linked to stable ones, assuring the stability of the whole slope. As discussed in the literature, roots under tension contribute to slope stabilisation, but those under compression may also contribute to the overall reinforcement and may play a major role (Schwarz and Cohen 2011). The efficiency of root reinforcement under compression may eventually depend on the geometry of the tree layout (squared, triangular, radial, etc.); further studies are needed to analyse this aspect.

The results in Fig. 7 show that the minimal lateral root reinforcement has a realistic range between 2 and $15 \mathrm{kN} \mathrm{m}^{-1}$, which in terms of mean distances between trees (see Fig. 5) corresponds to 5.5 and $18 \mathrm{~m}$ for poplar trees with $0.3 \mathrm{~m} \mathrm{DBH}$ (tree density of 330 and $30 \mathrm{sph}$, respectively). Comparing results obtained from the two datasets (G and PN) enables the possible range of lateral root reinforcement that could be expected for different tree spacings to be defined. As discussed previously, the difference in the two datasets results in an important difference in calculated lateral root reinforcement, which in turn gives an idea of the variability of slope stabilisation efficiency of a spaced tree population. Data on the estimated minimal effective tree distance derived from empirical studies (Douglas et al. 2013), $8 \times 8 \mathrm{~m}->160 \mathrm{sph}$, falls in the calculated range of values obtained in this study giving further weight to the approach developed here. However, it is important to emphasise that root distribution is highly variable and may not be represented by single values, but by a range of values.

The importance of trees to contribute to soil carbon has been widely recognised and therefore soil conservation trees have both environmental and a political relevance. For instance, requirements for claiming carbon credits are under discussion within the New Zealand Emissions Trading Scheme (ETS). A tree canopy cover of $30 \%$ is considered to provide a balance between carbon sequestration and the reduction of annual pasture production due to trees (estimated to be $10 \%$ less than from no trees).
Using the data reported by McIvor and Douglas (2012) for a $0.3-\mathrm{m} \mathrm{DBH}$ poplar tree, about $70 \mathrm{sph}$ is needed to achieve this balance. This corresponds to a mean stem spacing of about $12 \mathrm{~m}$. Comparing these data with the results of the present work, such a tree spacing would lead to lateral root reinforcement ranging between $0 \mathrm{kN}$ m ${ }^{-1}$ for the PN dataset and $16 \mathrm{kN} \mathrm{m}^{-1}$ for the $\mathrm{G}$ dataset. These results show that it is important to have complete information on root distribution characteristics in order to be able to perform quantitative analysis of the effect of spaced trees on the stability of hillslopes.

The relationship between tree $\mathrm{DBH}$ and canopy cover due to different spacings of poplar trees (30, 70, 130, and $210 \mathrm{sph}$ ) obtained with the information reported in McIvor and Douglas (2012) is shown in Fig. 10. Comparing the results at $30 \%$ canopy cover, it emerges that only for stem densities up to about $100 \mathrm{sph}$, it is possible to obtain such a percentage of canopy cover with tree DBHs ranging between 0.2 and $0.5 \mathrm{~m}$. Considering the combination of factors that would lead to $30 \%$ cover for a stem density of 30 and $70 \mathrm{sph}$ (points A and B in Fig. 10), the mean stem distance would be about 18 and $12 \mathrm{~m}$, respectively, meaning that the root system radius should reach 9 and $6 \mathrm{~m}$ in order to contribute to lateral root reinforcement at the hillslope scale. In favourable growing conditions (such as found in the case of the G dataset), these stem distances would lead to considerable lateral root reinforcement $\left(>15 \mathrm{kN} \mathrm{m}^{-1}\right)$, whereas for the $\mathrm{PN}$ dataset, the estimated lateral root reinforcement is about zero.

In this study, the results obtained for different dimensions of 'Veronese' poplar trees were compared, ranging from $66 \mathrm{~mm} \mathrm{DBH}$ for the 1-year-old pole in the $\mathrm{G}$ dataset to $300 \mathrm{~mm} \mathrm{DBH}$ for poles in the PN dataset in the 237 sph density plot. This range in $\mathrm{DBH}$ corresponds to the dimensions that poles of this clone may reach in 11 years of growth on a gentle hillslope. Assuming an age-DBH correlation, it would be possible to predict the temporal development of root reinforcement. This type of information would enable management strategies for spaced tree populations on slopes to be developed that would ensure constant minimal root reinforcement over a long period of time. For instance, if a high tree density was planted (300-400 sph), later thinning and pruning may optimise the density of trees in later years in view of growth rates and root distribution. A future valuable initiative would be to determine how thinning and pruning measures influence root distribution over time.

Even in the case where the mechanical effects of lateral roots on the stabilisation of shallow landslide are small or negligible, the hydrological effects of vegetation may still contribute to slope stabilisation. In fact, depending on the hydro-mechanical condition of the slope, vegetation may increase directly or 


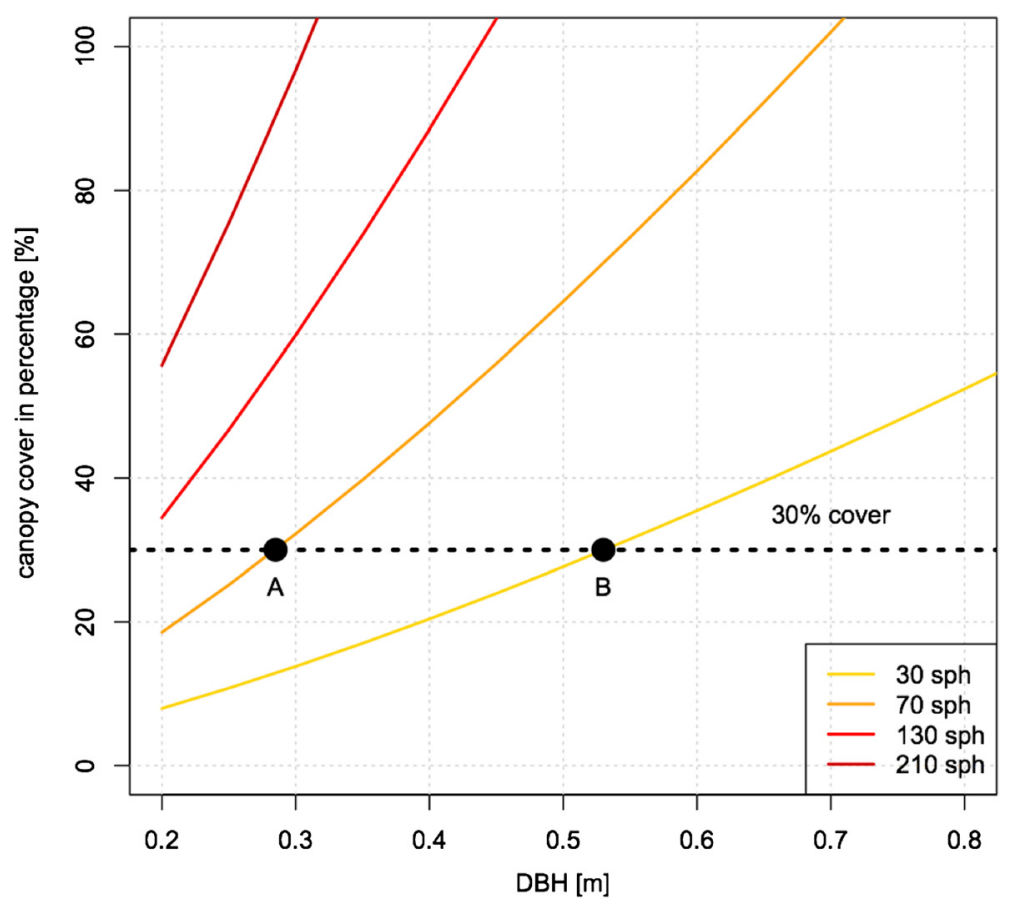

Fig. 10 Relationship between poplar DBH and percentage of canopy cover for different planting densities (stem per hectare $=$ sph). The values are calculated based on the data reported by Mclvor and Douglas (2012)

indirectly the matric suction and the permeability of the soil, enhancing slope stability. However, considering the typical hydrological conditions for the triggering of shallow landslides in New Zealand (Douglas et al. 2006; Wilkinson et al. 2002; Hawke and McConchie 2011), the hydrological effects of vegetation are strongly seasonally dependent and the stabilisation effects during intense and prolonged rainfall are likely to be limited.

The inclusion of poplar root distribution and tree size data in slope stability models in this study has provided valuable guidance on potential implications for pastoral hillside stability. The approach is believed to be the first for wide-spaced tree plantings. Although results have been restricted to young trees with maximum DBH of $0.3 \mathrm{~m}$, pastoral slopes with establishing trees are often the most vulnerable to shallow landslides and other erosion processes mainly because trees have small root systems compared with older trees (McIvor et al. 2008). The results support a strategy of planting at high density to hasten slope stabilisation and thinning later as canopies and roots develop, to facilitate growth of the pasture understorey.

In view of the results obtained in the current study, the authors suggest further research should focus on:

- Root distribution mapping of trenches on a representative ecological range of hillslopes, performing pullout tests of roots with diameters greater than $8 \mathrm{~mm}$ (eventually in different seasons),

- Quantifying the performance of different dimensions of planting material in terms of temporal development of lateral root reinforcement, and

- Performing event analysis for shallow landslides in view of a better stochastic characterisation of the frequency-magnitude relationship of such events.

\section{Conclusions}

This paper describes a unique quantitative approach that combines information about root distribution and root mechanical data in order to calculate the spatial distribution of root reinforcement as a function of tree dimension and distance between 'Veronese' poplar trees. The results were used to formulate guidelines for the planning of bioengineering measures with the aim of reducing erosion on pastoral hill slopes in New Zealand. The calculations show that the definition of effective planting density for the same poplar clone 'Veronese' is a function of the local root growing condition, the slope inclination, and the soil mechanical properties (effective friction angle and cohesion). Generally, it can be concluded that planting density that ranges between 330 and $160 \mathrm{sph}$ (corresponding to stem distance of 5.5 and $8 \mathrm{~m}$, respectively) would assure significant root reinforcement for slope stabilisation $\left(>2 \mathrm{kN} \mathrm{m}^{-1}\right)$ and reduce the volume of triggered shallow landslides by up to $100 \%$. In ideal growing conditions, tree spacing starting 
from $100 \mathrm{sph}$ is sufficient for stem DBH larger than $0.15 \mathrm{~m}$ to assure enough root reinforcement. A lower planting density would lead to less lateral root reinforcement, and the contribution of vegetation to slope stability would probably be limited to the hydrological effects.

\section{Endnotes}

${ }^{1}$ Watson, A, McIvor, IR, Douglas, GB. Live root-wood tensile strength of Populus $\mathrm{x}$ euramericana 'Veronese' poplar. Unpublished Landcare Research report prepared for FRST Contract CO2X0405 in 2007. http://www.poplarandwillow.org.nz/documents/veronese-poplar-paperlive-root-wood-strength.pdf. See Additional file 1.

\section{Additional file}

Additional file 1: Watson, A, Mclvor, IR, Douglas, GB. Live rootwood tensile strength ofPopulus $\times$ euramericana "Veronese" poplar. Unpublished Landcare Research report. (PDF $252 \mathrm{~kb}$ )

\section{Competing interests}

The authors declare that they have no competing interests.

\section{Authors' contributions}

MS carried out the numerical analysis and drafted the manuscript. CP and MM participated in the design of the study, provided the field data, contributed to the data analysis, and helped to draft the manuscript. IM and GD provided the field data and helped to draft the manuscript. AW provided the unpublished information. All authors read and approved the final manuscript.

\section{Authors' information}

MS is a forest engineer, scientific collaborator, and lecturer at the Bern University of Applied Sciences (CH). CP is a Portfolio Leader at Landcare Research (NZ). MM is a Researcher at Landcare Research (NZ). IM is a Senior Scientist at the New Zealand Institute for Plant \& Food Research (NZ). GD is a Senior Scientist at AgResearch (NZ). AW was a former researcher at Landcare Research, now retired.

\section{Author details}

${ }^{1}$ Bern University of Applied Sciences, 3052 Zollikofen, Switzerland. ${ }^{2}$ Swiss Federal Institute for Forest, Snow and Landscape Research, 8903 Birmensdorf, Switzerland. ${ }^{3}$ Landcare Research, PO Box 69040, Lincoln 7640, New Zealand. ${ }^{4}$ Landcare Research, PO Box 445, Gisborne 4010, New Zealand. ${ }^{5}$ Plant and Food Research, Private Bag, 11030 Palmerston North, New Zealand. ${ }^{6}$ AgResearch, Private Bag, 11008 Palmerston North, New Zealand. ${ }^{7} 2$ Head Street, Sumner, Christchurch 8081, New Zealand.

Received: 19 April 2015 Accepted: 19 January 2016

Published online: 03 February 2016

\section{References}

Ammer, C., \& Wagner, S. (2005). An approach for modelling the mean fine-root biomass of Norway spruce stands. Trees, 19, 145-153.

Basher, L. R. (2013). Erosion processes and their control in New Zealand. In J. R. Dymond (Ed.), Ecosystem services in New Zealand - conditions and trends (pp. 363-374). Lincoln, New Zealand: Manaaki Whenua Press.

Betteridge, K., Costall, D., Martin, S., Reidy, B., Stead, A., \& Millner, I. (2012). Impact of shade trees on Angus cow behaviour and physiology in summer dry hill country: grazing activity, skin temperature and nutrient transfer issues. In L. D. Currie \& C. L. Christensen (Eds.), Advanced nutrient management: gains from the past-goals for the future. [Occasional Report No. 25]. Palmerston North: Massey University Fertilizer and Lime Research Centre..
Blaschke, P. M., Trustrum, N. A., \& DeRose, R. C. (1992). Ecosystem processes and sustainable land use in New Zealand steeplands. Agriculture, Ecosystems \& Environment, 41, 153-178.

Blaschke, P, Hicks, D, Meister, A (2008). Quantification of the flood and erosion reduction benefits, and costs, of climate change mitigation measures in New Zealand. [Report prepared by Blaschke and Rutherford Environmental Consultants for MfE]. Wellington: Ministry for the Environment

Chiatante, D., Scippa, G. S., Di lorio, A., \& Sarnataro, M. (2003). The influence of steep slope on root system development. Journal of Plant Growth Regulation, 21, 247-260

Claessens, L., Schoorl, J. M., \& Veldkamp, A. (2007). Modeling the location and shallow landslides and their effects on landscape dynamics in large watersheds: an application for Northern New Zealand. Geomorphology, 87, 16-27.

Cohen, D., Schwarz, M., \& Or, D. (2011). An analytical fiber bundle model for pullout mechanics of root bundles. Journal of Geophysical Research, 116, F03010.

De Rose, R. C., Trustrum, N. A., Thomson, N. A., \& Roberts, A. H. C. (1995). Effect of landslide erosion on Taranaki hill pasture production and composition. New Zealand Journal of Agricultural Research, 38(4), 457-471.

Diggle, A. J. (1988). ROOTMAP_a model in three-dimensional coordinates of the growth and structure of fibrous root systems. Plant and Soil, 105, 169-178.

Douglas, G. B., Trustrum, N. A., \& Brown, I. C. (1986). Effect of soil slip erosion on Wairoa hill pasture production and composition. New Zealand Journal of Agricultural Research, 29(2), 183-192.

Douglas, G. B., Walcroft, A. S., Hurst, S. E., Potter, J. F., Foote, A. G., Fung, L. E., et al. (2006). Interactions between widely spaced young poplars (Populus spp.) and the understorey environment. Agroforest Systems, 67, 177-186.

Douglas, G. B., Mclvor, I. R., Potter, J. F., \& Foote, A. G. (2010). Root distribution of poplar at varying densities on pastoral hill country. Plant and Soil, 333, 147-161.

Douglas, G. B., Mclvor, I. R., Manderson, A. K., Koolaard, J. P., Todd, M., Braaksma, S. , et al. (2013). Reducing shallow landslide occurrence in pastoral hill country using wide-spaced trees. Land Degradation and Development, 24, 103-114. doi:10.1002/ldr.1106.

Dymond, J. R., Ausseil, A. G., Shepherd, J. D., \& Buettner, L. (2006). Validation of a region-wide model of landslide susceptibility in the Manawatu-Wanganui region of New Zealand. Geomorphology, 74(1-4), 70-79.

Giadrossich, F., Schwarz, M., Cohen, D., Preti, F., \& Or, D. (2012). Mechanical interactions between neighbouring roots during pullout tests. Plant and Soil. doi:10.1007/s11104-012-1475-1.

Glenz, C. (2005). Process-based, spatially-explicit modelling of riparian forest dynamics in Central Europe: tool for decision-making in river restoration. [PhD Thesis]. École polytechnique fédérale de Lausanne (EPFL). doi:10.5075/epflthesis-3223.

Hathaway, R. L., \& Penny, D. (1975). Root strength in some Populus and Salix clones. New Zealand Journal of Botany, 13, 333-344.

Hawke, R., \& McConchie, J. (2011). In situ measurement of soil moisture and pore-water pressures in an 'incipient' landslide: Lake Tutira, New Zealand. Journal of Environmental Management, 92(2), 266-274. doi:10.1016/j.jenvman. 2009.05.035.

Hawley, J. G., \& Dymond, J. R. (1988). How much do trees reduce landsliding? Journal of Soil and Water Conservation, 43, 495-498.

Heaphy, M., Lowe, D., Palmer, D., Jones, H., Gielen, G., Oliver, G., et al. (2014). Assessing drivers of plantation forest productivity on eroded and noneroded soils in hilly land, eastern North Island, New Zealand. New Zealand Journal of Forestry Science, 44: 24.

Hewitt, A.E. (1998). New Zealand soil classification. (2nd ed.). Lincoln, New Zealand: Manaaki Whenua-Landcare Research.

Kaldaron-Asael , B, Katz, O, Aharonov, E, Marco, S (2008). Modeling the relation between area and volume of landslides. [Report GSI/06/2008]. Jerusalem: Ministry of National Infrastructures Geological Survey of Israel.

Lambert, M. G., Trustrum, N. A., \& Costall, D. A. (1984). Effect of soil slip erosion on seasonally dry Wairarapa hill pastures. New Zealand Journal of Agricultural Research, 27(1), 57-64.

Lynch, J. P., Nielsen, K. L., Davis, R. D., \& Jablokow, A. G. (1997). SimRoot: modelling and visualisation of root systems. Plant and Soil, 188, 139-151.

Malamud, B. D., Turcotte, D. L., Guzzetti, F. \& Reichenbach, P. (2004). Landslide inventories and their statistical properties. Earth Surface Processes and Landforms, 29, 687-711.

Marden, M., Arnold, G., Gomez, B., \& Rowan, D. (2005). Pre- and post-reforestation gully development in Mangatu Forest, East Coast, North Island, New Zealand. River Research and Applications, 21, 757-771. 
Marden, M. (2012). Effectiveness of reforestation in erosion mitigation and implications for future sediment yields, East Coast catchments, New Zealand: a review. New Zealand Geographer, 68, 24-35.

Marden, M., \& Rowan, D. (2015). The effect of land use on slope failure and sediment generation in the Coromandel region of New Zealand following a major storm in 1995. New Zealand Journal of Forestry Science, 45: 10.

Marden, M., Rowan, D., \& Phillips, C. J. (1995). Impact of cyclone-induced landsliding on plantation forests and farmland in the East Coast of New Zealand: a lesson in risk management. In K. Sassa (Ed.), Proceedings of XX IUFRO World Congress, Tampere Finland 1995 (pp. 133-145).

Mclvor, IR, \& Douglas, GB (2012). Poplars and willows in hill country - stabilising soils and storing carbon. In L.D. Currie and C.L. Christensen (Eds.), Advanced Nutrient Management: Gains from the Past - Goals for the Future. ). [Occasional Report No. 25]. Palmerston North, New Zealand: Massey University Fertilizer and Lime Research Centre.

Mclvor, I. R., Metral, B., \& Douglas, G. B. (2005). Variation in root density of poplar trees at different plant densities. Proceedings of the Agronomy Society of New Zealand, 35, 66-73.

Mclvor, I. R., Douglas, G. B., Hurst, S. E., Hussain, Z., \& Foote, A. G. (2008). Structural root growth of young Veronese poplars on erodible slopes in the southern North Island, New Zealand. Agroforestry Systems, 72(1), 75-86. doi:10.1007/ s10457-007-9090-5.

Mclvor, I. R., Douglas, G. B., \& Benavides, R. (2009). Coarse root growth of Veronese poplar trees varies with position on an erodible slope in New Zealand. Agroforestry Systems, 76(1), 251-264. doi:10.1007/s10457-009-9209-y.

Mclvor, IR, Douglas, GB, Dymond, J, Eyles, G, Marden, M (2011). Pastoral hill slope erosion in New Zealand and the role of poplar and willow trees in its reduction. In D. Godone and S. Silvia (Eds.), Soil Erosion Issues in Agriculture. (pp. 257-278). InTech - Open Access Publisher http://www.intechopen.com/ articles/show/title/pastoral-hill-slope-erosion-in-new-zealand-and-the-role-ofpoplar-and-willow-trees-in-its-reduction.

Ozier-Lafontaine, H., Lecompte, F., \& Sillon, J. F. (1999). Fractal analysis of the root architecture of Gliricidia sepium for the spatial prediction of root branching, size and mass: model development and evaluation in agroforestry. Plant and Soil, 209, 167-180.

Pages, L., Vercambre, G., Drouet, J. L., Lecompte, F., Collet, C., \& Le Bot, J. (2004). Root Typ: a generic model to predict and analyse the root system architecture. Plant and Soil, 258, 103-119.

Pearce, AJ, O'Loughlin, CL, Jackson, RJ, Zhang, XB (1987). Reforestation: on-site effects on hydrology and erosion, eastern Raukumara Range, New Zealand. Forest Hydrology and Watershed Management. In Proceedings of the Vancouver Symposium (pp. 489-497). [IAHS-ASIH Publication No. 167]

Phillips, C. J., \& Marden, M. (2005). Reforestation schemes to manage regional landslide risk. In T. Glade, M. Anderson, \& M. J. Crozier (Eds.), Landslide hazard and risk (pp. 517-547). Chichester, UK: John Wiley.

Phillips, C. J., Marden, M., \& Pearce, A. (1990). Effectiveness of reforestation in prevention and control of landsliding during large cyclonic storms. In Proceedings XIX World IUFRO Congress, Montreal, Canada.

Phillips, C. J., Marden, M., \& Basher, L. (2012). Plantation forest harvesting and landscape response-what we know and what we need to know. New Zealand Journal of Forestry, 56(4), 4-12.

Phillips, C. J., Marden, M., \& Lambie, S. M. (2014). Observations of root growth of young poplar and willow planting types. New Zealand Journal of Forestry Science, 44:15.

Phillips, C. J., Marden, M., \& Lambie, S. M. (2015). Observations of "coarse" root development in young trees of nine exotic species from a New Zealand plot trial. New Zealand Journal of Forestry Science, 45: 13.

Pollen, N., \& Simon, A. (2005). Estimating the mechanical effects of riparian vegetation on streambank stability using a fiber bundle model. Water Resources Research, 41, W07025.

Rickli, C., \& Graf, F. (2009). Effects of forests on shallow landslides - case studies in Switzerland. Forest Snow and Landscape Research, 82(1), 33-44.

Roering, J. J., Schmidt, K. M., Stock, J. D., Dietrich, W. E., \& Montgomery, D. R. (2003). Shallow landsliding, root reinforcement, and the spatial distribution of trees in the Oregon Coast Range. Canadian Geotechnical Journal, 40, 237-253.

Rosser, B. J., \& Ross, C. W. (2011). Recovery of pasture production and soil properties on soil slip scars in erodible siltstone hill country, Wairarapa, New Zealand. New Zealand Journal of Agricultural Research, 54, 23-44.

Schiechtl, H. M. (1992). Weiden in der Praxis: Die Weiden Mitteleuropas und ihre Verwendung und ihre Bestimmung. Berlin: Patzer Verlag. $130 \mathrm{~S}$.
Schwarz, M., \& Cohen, D. (2011). Influence of root distribution and compressibility of rooted soil on the triggering mechanism of shallow landslides. [Geophysical Research Abstracts 13, EGU 2011-4817], EGU General Assembly 2011, Vienna, Austria.

Schwarz, M., Preti, F., Giadrossich, F., Lehmann, P., \& Or, D. (2010a). Quantifying the role of vegetation in slope stability: a case study in Tuscany (Italy). Ecological Engineering, 36, 285-291.

Schwarz, M., Lehmann, P., \& Or, D. (2010b). Quantifying lateral root reinforcement in steep slopes: from a bundle of roots to tree stands. Earth Surface Processes and Landform, 35, 354-367.

Schwarz, M., Cohen, D., \& Or, D. (2012a). Spatial characterization of root reinforcement at stand scale: theory and case study. Geomorphology, 171-172, 190-200. http://dx.doi.org/10.1016/j.geomorph.2012.05.020.

Schwarz, M., Thormann, J.J. , Zürcher, K., \& Feller, K. (2012b). Quantifying root reinforcement in protection forests: implication for slope stability and forest management. Proceedings of the Interpraevent 2012, Grenoble, France.

Schwarz, M., Feller, K. \& Thormann, J.J. (2013). Entwicklung und Validierung einer neuen Methode für die Beurteilung und Planung der minimalen Schutzwaldpflege auf rutschgefährdeten Hängen. [Final report to the Wald- und Holzforschungsfonds]. Bern: Swiss Federal Office for the Environment FOEN

Schwarz, M., Dorren, L., \& Thormann, J.J. (2014). SLIDEFORNET: a web tool for assessing the effect of root reinforcement on shallow landslides. In International Conference, "Analysis and Management of Changing Risks for Natural Hazards", 18-19 November 2014 I Padua, Italy

Schwarz, M., Rist, A., Cohen, D., Giadrossich, F., Egorov, P., Büttner, D., et al. (2015). Root reinforcement of soils under compression. Journal of Geophysical Research: Earth Surface, 120, 2103-2120. doi:10.1002/2015JF003632.

Sidle, R.C., \& Ochiai, H. (2006). Landslides: Processes, Prediction, and Land Use. Washington DC: American Geophysical Union.

Stokes, A., Atger, C., Bengough, A. G., Fourcaud, T., \& Sidle, R. C. (2009). Desirable plant root traits for protecting natural and engineered slopes against landslides. Plant and Soil, 324, 1-30.

Sulaiman, Z. (2006). Establishment and silvopastoral aspects of willow and poplar. [PhD Thesis], Institute of Natural Resources, Massey University, Palmerston North, New Zealand

Tobin, B., Cermak, J., Chiatante, D., Danjon, F., Di Orio, A., Dupuy, L., et al. (2007). Towards developmental modelling of tree root systems. Plant Biosystems, 141, 481-501.

Van Noordwijk, S. L. Y., \& de Willigen, P. (1994). Proximal root diameter as predictor of total root size for fractal branching models. Plant and Soil, 164, 107-117.

Wall, A. J., Mackay, A. D., Kemp, P. D., Gillingham, A. G., \& Edwards, W. R. (1997). The impact of widely spaced soil conservation trees on hill pastoral systems. Proceedings of the New Zealand Grassland Association, 59, 171-177.

Wang, Z., Guo, D., Wang, X., Gu, J., \& Mei, L. (2006). Fine root architecture, morphology, and biomass of different branch orders of two Chinese temperate tree species. Plant and Soil, 288, 155-171.

Wilkinson, A. G. (1999). Poplars and willows for soil erosion control in New Zealand. Biomass and Bioenergy, 16, 263-274.

Wilkinson, P. L., Anderson, M. G., \& Lloyd, D. M. (2002). An integrated hydrological model for rain-induced landslide prediction. Earth Surfaces, Processes and Landforms, 27(12), 1285-1297.

\section{Submit your manuscript to a SpringerOpen ${ }^{\circ}$ journal and benefit from:}

- Convenient online submission

- Rigorous peer review

- Immediate publication on acceptance

- Open access: articles freely available online

- High visibility within the field

- Retaining the copyright to your article

Submit your next manuscript at $>$ springeropen.com 